\title{
Laboratory Tests in the Diagnosis of COVID-19
}

\author{
COVID-19 Tanısında Laboratuvar Testleri
}

\author{
Şemsi Nur KARABELA \\ (i) 0000-0003-2562-3004 \\ Kadriye KART YAŞAR \\ (D) 0000-0003-2963-4894
}

University of Health Sciences Bakirköy Dr. Sadi Konuk Training and Research Hospital Infectious Diseases and Clinical Microbiology, Istanbul, Turkey

\section{Corresponding Author Sorumlu Yazar \\ Kadriye KART YAŞAR \\ hkkyasar@gmail.com}

Received / Gelis Tarihi : 01.09.2020 Accepted / Kabul Tarihi : 13.10.2020 Available Online /

Çevrimiçi Yayın Tarihi : 25.11.2020

\begin{abstract}
The gold standard for routine microbiological diagnosis of coronavirus disease 2019 (COVID-19) is quantitation of viral RNA in respiratory specimens by reverse-transcription polymerase chain reaction (RT-PCR). Detecting severe acute respiratory syndrome coronavirus 2 (SARS-CoV-2) specific IgM and IgG antibodies in patient sera are additional diagnostic tests. It has been known that virus release begins a few days before clinical signs appear, and therefore, beginning from 2-3 days before the manifestation of clinical symptoms, virus RNA can be detected in the respiratory tract during the symptomatic period of the disease. Since the viral load is higher in lower respiratory tract samples such as bronchoalveolar lavage and tracheal aspirate, PCR positivity rate might be found higher compared to nasopharyngeal samples. Confirmatory PCR tests require specific equipment and trained personnel, and they are also time-consuming and costly. Antibody assays are simple, faster tests, do not require much equipment and applicable in any laboratory. They can even be performed with 2-3 drops of blood collected from the finger tip of patients using relatively inexpensive chromatographicrapid tests. These tests can be used in the later period of the disease since specific antibodies appear on the $7-10^{\text {th }}$ day of clinical signs in patients with COVID-19. Rapid antibody card tests have an average specificity and sensitivity, while antibody tests using microELISA have higher sensitivity and specificity.
\end{abstract}

Keywords: COVID-19; PCR; antibody; serology.

ÖZ

Koronavirüs hastalığ 2019 (coronavirus disease 2019, COVID-19) için rutin mikrobiyolojik tanıda altın standart, solunum yolu örneklerinde viral RNA'nın gerçek zamanlı reverstranskriptaz polimeraz zincir reaksiyonu (RT-PCR) ile gösterilmesidir. Hasta serumunda şiddetli akut solunum yolu sendromu koronavirüsü 2 (severe acute respiratory syndrome coronavirus 2, SARS-CoV-2)'ye spesifik olan IgG ve IgM antikorların gösterilmesi de ek tanısal testlerdir. Virüs atılımının klinik bulgulardan birkaç gün öncesinden başladığı ve bu yüzden semptomların başlamasından 2-3 gün öncesinden itibaren klinik dönem boyunca virus RNA'sının solunum yollarında tespit edilebileceği bilinmektedir. Bronkoalveolar lavaj ve trakeal aspirat gibi alt solunum yolu örneklerinde viral yük daha fazla olduğundan PCR pozitiflik oranı nazofaringeal örneklere kıyasla daha yüksektir. Zaman alıcı ve pahalı olan doğrulayıcı PCR testleri, özel ekipman ve deneyimli personel gerektirir. Antikor testleri ise basit, hızlı sonuç verebilen, ciddi ekipman gerektirmeyen ve hemen her laboratuvarda yapılabilen testlerdir. Nispeten ucuz olan kramotografik hızlı kart testlerle parmak ucundan alınan 2-3 damla kanla, hasta başında bile yapılabilir. COVID-19 geçiren kişilerde hastalığın 7-10. gününden itibaren oluşan antikorlar sebebiyle, bu testler daha geç bir zamanda kullanılabilir. Hızlı antikor kart testleri ortalama bir özgüllük ve duyarlılığa sahipken, mikroELISA ile çalışılan antikor testlerinin duyarlılık ve spesivitesi ise daha yüksektir.

Anahtar kelimeler: COVID-19; PCR; antikor; seroloji. 


\section{INTRODUCTION}

The emerging coronavirus disease 2019 (COVID-19) is caused by a novel coronavirus which is in the same group of severe acute respiratory syndrome coronavirus (SARS-CoV) of 2003; therefore, it was named severe acute respiratory syndrome coronavirus 2 (SARS-CoV-2). COVID-19 led to a serious global pandemic affecting the whole world. The clinical spectrum of the disease ranges between asymptomatic infection and multiorgan failure. In fact, the essential clinical picture involves pneumonia and acute respiratory distress syndrome (ARDS) that develop in the lung tissue and thromboembolic events that emerge in the organs such as heart and brain. The gold standard of routine microbiological diagnosis for COVID-19 is the identification of viral RNA by real time reverse transcriptase polymerase chain reaction (RT-PCR) assay in the appropriate clinical samples obtained primarily from the respiratory tract. Besides the identification of the antigen in the clinical samples, the detection of the $\mathrm{IgG}$ and IgM type specific antibodies against SARS-CoV-2 is also critical for diagnosis.

In the present review, it was aimed to analyze the available laboratory tests and diagnostic stages that should be followed in the process of global COVID-19 pandemic affecting the whole world.

\section{GENERAL INFORMATION}

SARS-CoV-2 is a member of the Coronavirus family from the zoonotic RNA viruses. Coronaviruses (CoV), enveloped RNA viruses, have relatively large genomic structures with a single-strand, positive polarity, and a length of 27-32 kb. Infectious genomic RNA and N phosphoprotein constitute helical nucleocapsid. The lipoprotein envelope surrounding the virus consists of transmembrane matrix (M) glycoprotein and envelope (E) protein. Two types of spike-shaped protrusions are present on the $\mathrm{CoV}$ virion. The long $(20 \mathrm{~nm})$ and short protrusions comprise spike (S) and hemagglutinin-esterase (HE) glycoproteins, respectively $(1,2)$. Because of the crown-like appearance of these protrusions, these viruses have been named coronaviruses, meaning "crowned virus" and originating from the word "corona" which means "crown" in Latin. The SARS-CoV-2 genome contains at least six open reading frames (ORF). Two-third of its genome is composed of ORFs encoding non-structural proteins, while ORFs in the remaining one-third of the genome encode at least four (S, M, E, and N) structural proteins (3, Figure 1). The first described human pathogenic coronaviruses (CoVs) were $\mathrm{HCoV}-229 \mathrm{E}$ and $\mathrm{HCoV}-\mathrm{C} 43$, identified in the mid1960s. CoVs have four main genera -alpha, beta, gamma, and delta- that are further divided into subgenera. CoVs can cause diseases in mammals (bats, cats, dogs, and pigs, and various poultries as well as humans). SARS-CoV was identified in 2003, leading to a global pandemic, and has been shown to be $88 \%$ genetically identical with SARSCoV-2, the agent responsible for the ongoing 2019 pandemic $(4,5)$. SARS-CoV-2 is also a typical CoV and belongs to the betacoronavirus $2 b$ family, like SARS-CoV and Middle East respiratory syndrome coronaviruses (MERS-CoV).

Human CoVs can cause a wide range of diseases, varying from a simple cold to serious respiratory and multiorgan failures as in SARS, MERS, and COVID-19. The mortality rate of COVID-19 has been reported to be between
$0.1 \%$ and $21 \%$ (mean $3.5 \%$ ), which is lower than the rates for SARS-CoV (9.6\%) and MERS-CoV (34.4\%) (6-8). COVID-19 was first identified in pneumonia cases with unknown etiology in Wuhan City, China in December 2019, and subsequently shown to be caused by a novel virus. Being highly contagious, by September 2020, SARS-CoV-2 had caused 25 million cases of COVID-19.

\section{MICROBIOLOGICAL DIAGNOSIS OF COVID-19}

The incubation period of COVID-19 is 2-14 days (average, 5.2 days), and virus excretion is considered to begin a few days before the manifestation of clinical symptoms. Viral RNA can be detected in the respiratory tracts as long as the symptoms continue, beginning from 2-3 days before the emergence of the clinical symptoms. Since samples obtained from the lower respiratory tract, such as bronchoalveolar lavage and tracheal aspirate, have a higher viral load, a higher PCR positivity rate might be detected in those samples than nasopharyngeal samples. PCR positivity rates in the samples from the lower respiratory tract such as lavage and aspirate were $93 \%$ and $69 \%$, respectively $(9,10)$.

It has been demonstrated that the virus is replicated in the gastrointestinal system, and that alive virus is excreted in the stool. Nevertheless, transmission via the fecal-oral route remains unclear (11). PCR assays used for confirmation of the diagnosis have several disadvantages, such as the need for appropriate equipment and experienced personnel, its time-consuming nature $(5-6 \mathrm{~h}$ even for the fastest laboratories) and high testing costs (10).

The detection of the IgG and IgM type-specific antibodies that form against SARS-CoV-2 in the blood serum of the patient is also critical in diagnosis as well as in the identification of SARS-CoV-2-specific antigens in the clinical samples (12,13, Figure 2). The tests based on the detection of the antigens in the clinical samples are not recommended since they have low specificity and sensitivity levels. However, antibody testing is useful in cases that cannot be confirmed by PCR despite the presence of clinical symptoms. The guiding impact of antibody testing is incontrovertible in surveillance studies due to contact isolation, rapid detection and early treatment of infected subjects and prevention of disease progression towards advanced stages. These tests also have an important supportive effect in early and accurate diagnosis of COVID-19, while treatment modalities are controversial and given the lack of vaccination. The transmission of the virus to the sensitive subject groups can be prevented by early diagnosis in asymptomatic or mild cases. Antibody testing is an easily applicable and rapid test that can be performed in almost all laboratories without the requirement of advanced equipment, even at the bedside for rapid tests by collecting 2-3 drops of finger-prick blood samples. The only disadvantage of these tests is their applicability after later periods in the subjects who had COVID-19 since the antibodies emerge after the seventh to tenth day of the disease.

IgG and IgM type-specific antibodies that emerge in the serum of the patient can be detected by high sensitivity and specificity using the devices found in a typical microbiology laboratory or manually from human blood serum using the microELISA method for the detection of 
antibodies. On the other hand, the qualitative rapid card-based tests commonly used during the pandemic period for chromatographic detection of antibodies have an average specificity and sensitivity comparable with PCR and microELISA tests (12). The easily applicable antibody card-based tests without the requirement of experience and equipment also have other advantages such as rapid results and low-cost.

Although SARS-CoV-2 causes temporary viremia in the blood, there is no evidence of viral transmission via transfusion of blood products (9).

As a consequence, the essential samples that can be used for the diagnosis of COVID-19 are the specimens from the respiratory tracts and patient sera. Besides this, the following should be kept in mind as critical facts: the samples obtained from the lower respiratory tracts likely contain a higher level of viral load compared with the upper respiratory tracts; viral detection rate can be elevated in the samples obtained from the upper respiratory tract by concurrent nasopharyngeal and oro-pharyngeal swab sampling and transferring to an identical viral transport media, if possible; and performing nasopharyngeal sampling very deeply (inducing lacrimation and gagging) is ideal. Polyester or Dacron swabs should be used to avoid an adverse impact on PCR reaction, and those antibody tests might be significant and helpful only after the tenth day of the clinical process in the patients with COVID-19.

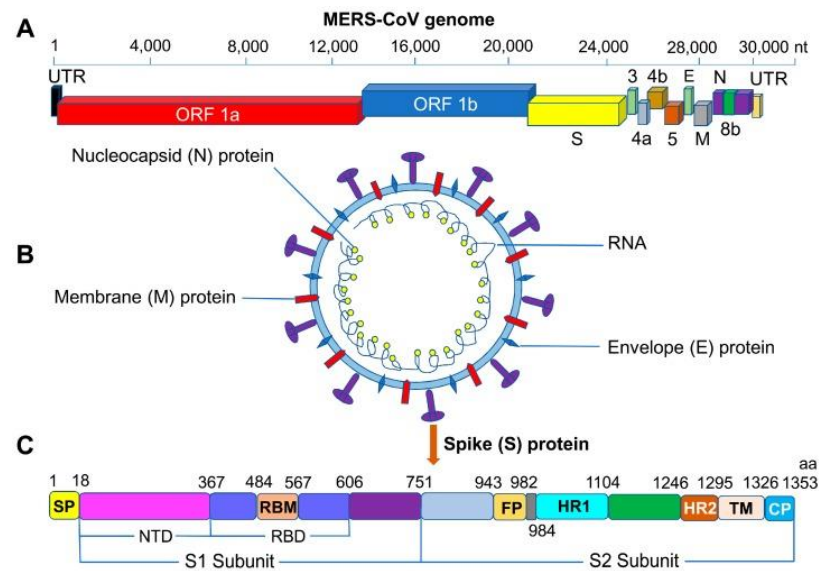

Figure 1. The genomic structure of SARS-CoV-2 and MERS-CoV (3)

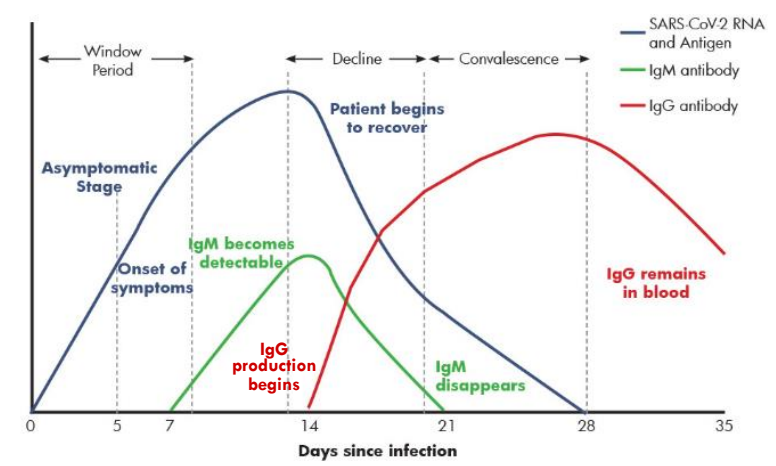

Figure 2. The clinical correlation of the COVID-19specific PCR and serological tests (13)

\section{PCR Tests}

The gold standard of routine microbiological diagnosis for COVID-19 is the identification of SARS-CoV-2 RNA by PCR (RT-PCR) in respiratory tract samples. RNA extraction from the appropriate clinical samples and PCR procedures should be carried out in molecular microbiology laboratories that have experience and adequate technical infrastructure in this field. Biosafety level 2 (BSL 2) precautions should be followed, beginning with the acceptance of the samples by the laboratory, and it should be assured that authorized laboratory staff trained in this field must work in BSL 2 cabinet using personal protective equipment.

Viral RNA might be detected in the respiratory tracts by PCR as long as the symptoms continue, beginning from 23 days before the emergence of the clinical symptoms. Since the samples obtained from the lower respiratory tract (bronchoalveolar lavage, tracheal aspirate, and sputum) have a higher viral load, the PCR positivity rate of those samples is higher than that of nasopharyngeal samples (10). Viral clearance can be achieved in the first ten days, whereas this period can prolong to six weeks in serious cases. Even though pharyngeal samples become negative, viral excretion in sputum or stool might last longer. Viral RNA can be identified in $30-60 \%$ of the COVID-19 patients by PCR tests (14).

The virus detection rate of PCR tests varies with various factors such as the releasing time of SARS-CoV-2 from the respiratory tract, sampling techniques, storage or transfer conditions during pre-analytical processes, or PCR experience of the working laboratory (Table 1). Therefore, PCR tests should be repeated within 24-48 $\mathrm{h}$ in COVID-19 suspected patients. Even if the RT-PCR tests used today are tests validated for the respiratory tract, various studies have shown that SARS-CoV-2 RNA can be isolated in cerebrospinal fluid and tear samples. In contrast, SARS-CoV-2 RNA is not detected in breast milk, amniotic fluid, and genital samples $(15,16)$. It has been reported that in COVID-19 cases the virus load (which is normally only high in the early period) is high in all periods and prolonged especially in the elderly and those with severe diseases. High and prolonged viral load is known as an important prognostic factor for COVID-19 $(17,18)$.

The target gene regions used in RT-PCR tests are on the RdRp, E, N, and S genes, and it is known that the best results are obtained with the E and RdRp genes $(9,19)$. Nucleic acid sequence analysis can also be used when necessary. The local PCR kit (that was produced in Turkey and distributed free of charge to authorized COVID-19 diagnostic laboratories by the Turkish Ministry of Health) also targets the $\mathrm{RdRp}$ and $\mathrm{N}$ gene region and has a sensitivity of $99.4 \%$ and a specificity of $99 \%$ (9).

Table 1. Factors contributing to the false-negative PCR (18)

- Poor quality sample with very little patient material

- A sampling at a very early or late period of COVID-19 infection

- A sample not properly processed and/or sent to the laboratory under unsuitable conditions

- Taking samples with cotton-tipped or wooden-shaft swabs

- Technical reasons inherent in the test such as PCR inhibition or virus mutation

- Wavy scattering of the SARS-CoV-2 virus into the respiratory tract in symptomatic and asymptomatic cases 


\section{Antibody Tests}

The long time needed to get PCR test results, high cost, and requirement of experienced medical staff for implementation and interpretation have driven efforts to identify easier and more rapidly applicable tests for diagnosis of SARS-CoV-2. Despite the rapidly increased number of serological tests worldwide to detect SARSCoV-2 antibodies thanks to supporting the attitude of the FDA on the regulation of the serological diagnostic tests at the beginning of the pandemic, these tests were used only in limited sampling groups $(20,21)$.

Even though different results that have been obtained in the various tests used to assess the presence of the antibodies clear the usage field of serology, no consensus on this issue could be established because of the contradictory results (22). Infectious Diseases Society of America (IDSA) has recommended the use of serological studies in the selection of plasma donors, vaccination evaluation, and epidemiological studies in the patients with clinical symptoms despite negative results for SARSCoV-2 RNA (23).

At the beginning of the pandemic, both IDSA and the World Health Organization (WHO) suggested that the presence of positive antibodies should be interpreted in favor of immunization; nevertheless, no study has yet determined whether immunization can be achieved in humans. The WHO is still examining the evidence on the antibody responses against the SARS-CoV-2 infection (24).

Since immune plasma obtained from the subjects who had recovered from COVID-19 contributed to recovery, the antibodies formed in these procedures were thought to be protective against SARS-CoV-2 (25-27). However, uncertainties remain because the specificity and titration of the epitope have not been determined. Of the 12 commercially available and approved antibody kits, only five could assess IgG solely, and three could assess both IgG and IgM. Subsequent studies have reported conflicting findings on titrations $(28,29)$. An important antigenic similarity is present between SARS-CoV-2 and other seasonal coronaviruses, and this point indicates the importance of antigen selection for serological tests for high specificity. Even the sensitivity levels of those serological tests based on the antibodies that are formed against the $\mathrm{N}$ or $\mathrm{S}$ proteins of the virus and approved by the reference centers such as FDA and EUA were low. This is because cross-reactions with other coronaviruses could not be prevented (20,30).

Although serological tests intended for use against a rapidly spreading pandemic should have a high positive predictive value and high specificity, the antibody tests used for SARS-CoV-2 do not meet these requirements (20,31). Another study that evaluated the adequacy of serological tests reported that the four most well-known antibody tests with adequate specificity and sensitivity became positive on the tenth day of the disease, at the earliest; therefore, this outcome narrowed the usable window of serological tests in the diagnosis of COVID-19 (32).

Circumstances that affect the formation of antibodies should be kept in mind. For example, cancer patients have significantly lower seroconversion rates than healthcare professionals (33).
As a consequence, because of inadequate quality and low sensitivity levels, serological diagnostic kits used to assess SARS-CoV-2 IgM and IgG should not yet be used for general screening of the SARS-CoV-2 pandemic (34).

\section{CONCLUSION}

The gold standard for routine microbiological diagnosis of COVID-19 is quantitation of viral RNA in respiratory specimens by PCR. Detection of specific IgM and IgG antibodies for SARS-CoV-2 in patients' sera might be helpful tests in COVID-19 diagnosis. Virus detection rate of PCR tests vary on various factors such as the releasing time of SARS-CoV-2 from the respiratory tract, sampling techniques, storage or transfer conditions during preanalytical processes, or PCR experience of the working laboratory. Specific IgM and IgG antibodies for SARSCoV-2 in patients' sera might be useful after the $10^{\text {th }}$ day of clinical signs. Negativity of PCR tests and antibody tests cannot exclude COVID-19. Therefore, patients should be evaluated together with clinical, laboratory and radiological findings.

Conflict of Interest: None declared by the authors.

Financial Disclosure: None declared by the authors.

Acknowledgements: None declared by the authors.

\section{REFERENCES}

1. Channappanavar R, Perlman S. Pathogenic human coronavirus infections: causes and consequences of cytokine storm and immunopathology. Semin Immunopathol. 2017;39(5):529-39.

2. Pabbaraju K, Fox JD. Coronaviruses. In: Versalovic J, Carrol KC, Funke G, Jorgensen JH, Landry ML, Warnock DW, editors. Manual of clinical microbiology. $10^{\text {th }}$ ed. Washington, DC: ASM Press; 2011. p.1410-22.

3. Zhou Y, Yang Y, Huang J, Jiang S, Du L. Advances in MERS-CoV vaccines and therapeutics based on the receptor-binding domain. Viruses. 2019;11(1):60.

4. Drosten C, Günther S, Preiser W, van der Werf S, Brodt HR, Becker S, et al. Identification of a novel coronavirus in patients with severe acute respiratory syndrome. N Engl J Med 2003;348(20):1967-76.

5. Lu R, Zhao X, Li J, Niu P, Yang B, Wu H, et al. Genomic characterisation and epidemiology of 2019 novel coronavirus: implications for virus origins and receptor binding. Lancet. 2020;395(10224):565-74.

6. Özturk R, Taşova Y, Ayaz A. COVID-19: pathogenesis, genetic polymorphism, clinical features and laboratory findings. Turk J Med Sci. 2020;50(SI1):638-57.

7. Liang LL, Tseng C, Ho HJ, Wu CY. Covid-19 mortality is negatively associated with test number and government effectiveness. Sci Rep. 2020;10(1):12567.

8. Bonadad C, García-Blas S, Tarazona-Santabalbina F, Sanchis J, Bertomeu-González V, Fácila L, et al. The effect of age on mortality in patients with COVID-19: A meta-analysis with 611,583 subjects. J Am Med Dir Assoc. 2020;21(7):915-8.

9. Öcal D, Vezir S, Karahan ZC. Mikrobiyolojik tanı yöntemleri. In: Memikoglu $\mathrm{O}$, Genç $\mathrm{V}$, editors. 
COVID-19. Ankara, Turkey: Ankara Üniversitesi Basımevi; 2020. p.17-27.

10. Yang Y, Yang M, Shen C, Wang F, Yuan J, Li J, et al. Evaluating the accuracy of different respiratory specimens in the laboratory diagnosis and monitoring the viral shedding of 2019-nCoV infections. MedRxiv. 2020. doi:10.1101/2020.02.11.20021493

11. Jiang F, Deng L, Zhang L, Cai Y, Cheung CW, Xia Z. Review of the clinical characteristic of coronavirus disease 19 (COVID-19). J Gen Intern Med. 2020;35(5):1545-9.

12. Imai K, Tabata S, Ikeda M, Nocuchi S, Kitagawa Y, Matuoka $M$, et al. Clinical evaluation of an immunochromatographic $\operatorname{IgM} / \operatorname{IgG}$ antibody assay and chest computed tomography for the diagnosis of COVID-19. J Clin Virol. 2020;128:104393.

13. Anudeep TC, Jeyaraman M, Shetty DU, Raj MH, Ajay SS, Somasundaram R, et al. Convalescent plasma as a plausible therapeutic option for nCOVID-19: A Review. J Clin Trials. 2020;10(3):409.

14. Ai T, Yang Z, Hou H, Zhang C, Chen C, Lv W, et al. Correlation of chest CT and RTPCR testing in coronavirus disease 2019 (COVID-19) in China: A report of 1014 cases. Radiology. 2020;296(2):E32-40.

15. Huang YH, Jiang D, Huang JT. SARS-CoV-2 detected in cerebrospinal fluid by PCR in a case of COVID-19 encephalitis. Brain Behav Immun. 2020;87:149.

16. Xia J, Tong J, Liu M, Shen Y, Guo D. Evaluation of coronavirus in tears and conjunctival secretions of patients with SARS-CoV-2 infection. J Med Virol. 2020;92(6):589-94.

17. Yu F, Yan L, Wang N, Yang S, Wang L, Tang Y, et al. Quantitative detection and viral load analysis of SARSCoV-2 in infected patients. Clin Infect Dis. 2020;71(15):793-8.

18. hsgm.saglik.gov.tr [Internet]. T.C. Sağlık Bakanlığ Halk Sağlığı Genel Müdürlüğü. COVID-19 (SARSCoV-2 Enfeksiyonu) Rehberi [Cited: 2020 August 31]. Available from: https://dosyamerkez.saglik.gov.tr/ Eklenti/37044,covid-19rehberipdf.pdf?0.

19. Corman VM, Landt O, Kaiser M, Molenkamp R, Meijer A, Chu DKW, et al. Detection of 2019 novel coronavirus (2019-nCoV) by real-time RT-PCR. Euro Surveill. 2020;25(3):2000045.

20. Tang MS, Hock KG, Logsdon NM, Hayes JE, Gronowski AM, Anderson NW, et al. Clinical performance of two SARS-CoV-2 serologic assays. Clin Chem. 2020;66(8):1055-62.

21. Okba NMA, Müller MA, Li W, Wang C, GeurtsvanKessel CH, Corman VM, et al. Severe acute respiratory syndrome coronavirus 2 -specific antibody responses in coronavirus disease patients. Emerg Infect Dis. 2020;26(7):1478-88.

22. Theel ES, Slev P, Wheeler S, Couturier MR, Wong SJ, Kadkhoda K. The role of antibody testing for SARS-
CoV-2: Is there one? J Clin Microbiol. 2020;58(8):e00797-20.

23. idsociety.org [Internet]. Infectious Diseases Society of America. IDSA COVID-19 Antibody Testing Primer [Cited: 2020 August 31]. Available from: https://www.idsociety.org/globalassets/idsa/publichealth/covid-19/idsa-covid-19-antibody-testingprimer.pdf.

24. who.int [Internet]. World Health Organization. "Immunity passports" in the context of COVID-19, scientific brief. [Cited: 2020 August 31]. Available from: https://apps.who.int/iris/rest/bitstreams/1275788/retrieve

25. Shen C, Wang Z, Zhao F, Yang Y, Li J, Yuan J, et al. Treatment of 5 critically Ill patients with COVID-19 with convalescent plasma. JAMA. 2020;323(16):15829.

26. Duan K, Liu B, Li C, Zhang H, Yu T, Qu J, et al. Effectiveness of convalescent plasma therapy in severe COVID-19 patients. Proc Natl Acad Sci USA. 2020;117(17):9490-6.

27. Bloch EM, Shoham S, Casadevall A, Sachais BS, Shaz B, Winters JL, et al. Deployment of convalescent plasma for the prevention and treatment of COVID-19. J Clin Invest 2020;130(6):2757-65.

28. fda.gov [Internet]. Food and Drug Administration. Coronavirus Disease 2019 (COVID-19) Emergency Use Authorizations for Medical Devices [Cited: 2020 August 31]. Available from: https://www.fda.gov/medicaldevices/emergency-use-authorizations-medicaldevices/coronavirus-disease-2019-covid-19emergency-use-authorizations-medical-devices.

29. Zhao J, Yuan Q, Wang H, Liu W, Liao X, Su Y, et al. Antibody responses to SARS-CoV-2 in patients of novel coronavirus disease 2019. Clin Infect Dis. 2020; [Epub ahead of print]. doi: 10.1093/cid/ciaa344.

30. Tay MZ, Poh CM, Rénia L, MacAry PA, Lisa FPNg. The trinity of COVID-19: immunity, inflammation and intervention. Nat Rev Immunol. 2020;20(6):363-74.

31. Farnsworth CW, Anderson NW. SARS-CoV-2 serology: much hype, little data. Clin Chem. 2020;66(7):875-7.

32. Krüttgen A, Cornelissen CG, Dreher M, Hornef M, Imöhl M, Kleines $M$. Comparison of four new commercial serologic assays for determination of SARS-CoV-2 IgG. J Clin Virol. 2020;128:104394.

33. Solodky ML, Galvez C, Russias B, Detourbet $\mathrm{P}$, N'Guyen-Bonin V, Herr AL, et al. Lower detection rates of SARS-CoV2 antibodies in cancer patients versus health care workers after symptomatic COVID19. Ann Oncol. 2020;31(8):1087-8.

34. Zhao R, Li M, Song H, Chen J, Ren W, Feng Y, et al. Early detection of SARS-CoV-2 antibodies in COVID19 patients as a serologic marker of infection. Clin Infect Dis. 2020; [Epub ahead of print]. doi: 10.1093/cid/ciaa523. 